\section{The auditor's role in the context of the accounting regulations evolution}

lonela POIDA (IVAN),

Doctoral School of Accounting, Bucharest Academy of Economic Studies, E-mail: ivan_v_ionela@yahoo.com

To cite this article:

Poida (Ivan), I., (2018), The auditor's role in the context of the accounting regulations evolution, Audit Financiar,

vol. XVI, no. 2(150)/2018, pp. 293-300,

DOI: 10.20869/AUDITF/2018/150/015

To link to this article:

http://dx.doi.org/10.20869/AUDITF/2018/150/015

Received: 09.02.2018

Revised: 15.03 .2018

Accepted: 23.03.2018

\section{Anstract}

The purpose of this paper is to demonstrate the importance of the auditors 'role in validating the appropriate application of the International Financial Reporting Standards as a result of numerous changes and the complex situations from day to day, from the perspective of choosing the right method, respectively from the perspective of verifying compliance with these standards.

The harmonization of the provided information facilitates the comparison in time and between companies, ensuring consistency a more granular discipline in reflecting the economic transactions.

The aim is to achieve the harmonization of the accounting methods and principles by adopting the same set of Accounting Standards. Having the normalization process as a starting point, the harmonization can be achieved through a convergence process built by gathering all the useful and constructive information from the past experiences. The main objectives are to use the same language and to quantify the impact of change using the same set of tools. The distinctive element relates to the culture of each organization, but the way in which the financial statements are prepared and the way in which they are presented will remain the same if the full harmonization is achieved.

Most of the time, the auditor has to assess the impact of an accounting selection at the expense of another option and to decide whether the results obtained, respectively the information provided by the entity are accurate and do not include misstatements that could significantly affect the financial statements.

The selection process involves evaluating the results compared to the objectives set by the regulatory system. The role of the auditor is to assess the degree of compliance of the financial statements with an applicable financial reporting framework. The auditor's objectives are to obtain reasonable assurance that the financial statements taken as a whole are free from material misstatements which may be caused by error or fraud and to issue an audit report that includes the audit opinion. The auditor's integrity and objectivity are directly 
related to the freedom from any constraint, which could affect the expression of the audit opinion. In other words, the auditor should never be affected by the influences that might compromise the professional judgment.

The speed of the changes from accounting may compromise the way in which the professional judgment is applied due to the complexity of certain cases. The International Auditing Standards provide the following guideline: when the auditor is no longer in a position to evaluate a case, a specialist/expert may be contracted.

The loss of independence occurs when the auditor is influenced by the client to "overlook" certain deviations from the provisions of the International Financial Reporting Standards.

The evolution of the accounting standards directly impacts the auditor's activity, as it is also shown in the study presented below. The results obtained can be extrapolated as the study focuses on a research related to the quantification of the impact of regulatory developments on the auditor's work.

Keywords: the evolution of the regulations, principles based accounting, fair value presentation, financial reporting, and financial statements.

JEL Classification: M 410
The difficulties in quantifying the impact of the changes in the accounting policies in the context of this evolution of International Accounting Standards depend upon the availability of the resources needed to determine it. Auditors have the role of verifying the actions of the managers who wish to present through the financial statements a favorable image of the entity's economic reality. It is essential that the principles laid down by the accounting standards are always up to date, and in order to verify this, a sufficient and detailed analysis of the information is required by comparing the results of the selected methods.

It is mandatory, in the case of a change in accounting policy, for example, to present the nature of the changes in the notes to the financial statements and the reasons why the application of the new policy provides credible and more relevant information to the users. The auditors' opinion is not influenced by the change in accounting policy as long as this has been done in compliance with the regulations on changes in accounting policies and, in particular, whether the new policy leads to the production of better quality, more credible and more relevant information to ensure that the image of the financial statements is properly reflected.

There will always be an element of uncertainty about the future. For example, when determining the revenue estimates, neither the legislation, nor the regulations can reduce many controversies which already exist, since an "uncertainty element" is associated with the amount presented in the financial statements for the annual profit figure (Brief, 1975).

The auditor's behavior is also influenced by the culture and the system of values of the audit company where they work. At the same time, the influence of culture on accounting must be taken into account in the development of ideas about the international classifications (Salterand, Niswander, 1995).

The Independent Auditor has the obligation to ensure that the policies and accounting principles adopted by the audited company are the most appropriate in those particular circumstances, applying the professional judgment and should not issue the audit opinion until all the significant aspects of the prescribed treatment have been verified in accordance with the International Financial Reporting Standards (Shafer, Ketchand and Morri, 2004). 


\section{Research methodology}

The research methodology used is the fundamental research, based on data analysis and the past research from the literature (literature review process) that seeks to verify the hypothesis according to which the evolution of the International Reporting Standards affects both the accountants and the auditors. The research also used the questionnaire to analyze the impact of the evolution of accounting standards upon the auditors' activity.

Another purpose of the research is to identify the difficulties in adapting to the changes in the International Financial Reporting Standards. The desired result is to reflect the financial operations, being compliant with all the accounting principles, by choosing the accounting options which lead to the complete disclosure of the economic substance that the auditors verify through the audit tests.

\section{The auditor's indenendence and his/ her role in an audit engagement}

External auditors play a very important role and the objectives set by them in each audit mission contribute to the validation of the financial statements. The essence of the audit is this validation (verification) (Antle, 1982).

Due to the flexibility of the existing regulatory framework, on the one hand, and the nature of the professional responsibilities, on the other hand, behind the auditor's conclusion, the audit opinion is in "the spotlight" and there must be sufficient documentation of the procedures applied during the audit exercise.

If there is adequate documentation of the company's choice of accounting options, the arguments for switching from one option to another are easier to support. The higher the complexity of a problem, the more the accounting standard may be more flexible so as to allow the choice of the right option depending on the specificity of each company's activity. That is why the audit tests are tailored to the profile of the audit client and the risks that are identified in the planning stage.

An audit opinion that is not supported by sufficient audit tests cannot be validated. Ultimately, the role of the auditor is related to the existence of robust documentation to verify the proper application of the accounting standards and, in their review practices, both the independence and the auditor's competence are assessed in the light of the effort to assess how the action to reflect the entity's economic reality and whether it is appropriate.

The normalization process has also experienced a significant evolution, with an impact on the way in which professionals carry on their work. Normalization contributes to substantiating accounting theory by showing what "must be" accounting and the following objectives are proposed (Feleagă, 1996):

- to ensure the regulation of accounting policies and thus improve accounting;

- to enable accountancy users to make rational decisions on the basis of accounting information;

- to create a climate of trust between the owners of capital and business managers;

- to serve as an arbitrary among the various parties involved in economy, and in particular between the producers of accounting information and the auditors who certify the quality of the information, thus ensuring the credibility of the accounting information.

Normalization can also be defined as the "standardization process of accounting records regularly reported by companies (financial statements) by defining the accounting terminology, the objectives and methodology (principles, processes, tools) and by settling contradictory interests regarding the content and structure of the financial statements "(Stănciulescu, 2008).

In the field of accounting, the language is a normalized one, which ensures consistency and completeness. The accounting language is characterized as having a simplifying character because most of the times, the accounting models do not identify themselves with the event (phenomena) represented (Feleagă, 2007). In order to ensure the transparency of information, the accounting language used must be universal, wellknown and understood by all the users of financial and accounting information, not only by the managers and shareholders.

Accounting harmonization has the ultimate objective of designing a common set of rules, policies and accounting principles that, after being applied, present a true and fair view of the financial position and the performance results of a company, regardless of the 
country in which it operates. The country's accounting system is dependent on the exchanges it develops with other countries, and the normalization of accounting aims to create a unitary system based on the harmonization of accounting methods, accounting terms, achieving that homogeneous information that adds value to all the users of the financial information. The use of these findings as a result of the application of wellestablished norms and principles leads to a beneficial uniformity in many ways, especially through a better allocation of resources (Feleagă, 1999).

In each audit engagement, an auditor starts with an analysis of the accounting principles and policies adopted by an entity, since they represent the basis upon which the audit tests are built. If the transition from a rule-based accounting to a principle-based accounting is made, verification of the results of this impact is done by applying the professional judgement.

The value of an audit can largely depend on how the auditor's independence is perceived by the involved partners. In practice, independence means adopting an unbiased view in the framework of the audit mission (Țogoe, 2012).

Auditor independence is an important element in ensuring the "objectivity" of accounting information for third parties, and in particular shareholders or associates. The level of independence increases if auditors' access to all specialized knowledge is unlimited, including the information provided by the internal audit.

In the work of an entity, the two functions, internal audit and management control are complementary and might support the external auditors in a considerable way. Internal audit contributes to management control and the external auditor's access to the reports that are considered relevant is very important because external audit can use verified information in auditing tests to guarantee the quality of the information.

\section{Proper documentation}

It is very important to document each change in accounting policy by analyzing the impact of applying the updated accounting standards and retrospective treatment where appropriate.

The questions that apply are the following:

- Has the alternative treatment allowed by the accounting standards been documented, including how it has been revealed?
- Is the effort and the documentation properly presented with the importance and complexity of the conclusion reached after applying the changes imposed by the updating of the accounting standards?

\section{Problem identification}

The main role of financial audit is to formulate an opinion by qualified persons on the compliance of information disseminated to external users through financial reporting with the reporting entity's status (Toma, 2012).

Audit opinion depends to a large extent on the compliance with the International Auditing Standards, but also on the verification of the results of the selection of those accounting policies and estimation techniques, depending on the entity's profile, applied to reflect the useful information to those analyzing the financial statements.

IAS 1, Presentation of Financial Statements requires companies that prepare their financial statements in accordance with International Financial Reporting Standards to present in the notes to the financial statements the accounting policies selected in an organized and systematic manner and the arguments for deviations from certain policy provisions, through a concrete reflection of the results of the choice of that method, to the detriment of the other method. Also, if there is a policy change, comparative information should be provided, except for the case of practical impossibility.

For example, a government grant that is granted for the purpose of providing immediate financial support to an entity, involves recognition in the profit and loss account in the period in which the entity qualifies for the grant. Therefore, it is necessary for the entity to provide in the explanatory notes information on the grant received, its purpose and the manner in which the conditions for granting the grant have been met.

There are at least two reasons why obtaining government assistance may be important in preparing an entity's financial statements. The first concerns the way of accounting for the transfer of resources and the second one is to ensure the comparability of the financial statements with those of previous exercises and with those of other entities (Gîrbină, Bunea, 2008).

In the case of a land subsidy, the construction of a building on that land may be a necessary condition. In 
this case, the grant is recognized in the profit and loss account over the life of the building.

In other words, the entity discloses in the explanatory notes both information on the conditions that have not been met in relation to government subsidies and the obligations deriving from their non-fulfillment.

Lease accounts may lead to transactions associated with the achievement of certain manager's goals, which, according to the auditors' analysis, negatively affects the transparency and full disclosure of the information in the financial statements. Examples of this are Enron's trades with limited liability companies, which meant that his debts and recorded losses were not reported in the financial statements (Frecka, 2008).

\section{Examples of the impact of regulatory developments}

A strong argument in favor of international accounting harmonization concerns the will of states to unify the conditions of competition between countries to the pressure of investors because if one or more states have a more flexible or pre-emptive accounting system, the entities are tempted to migrate through their capital to those areas.

Over time, the evolution of standards has taken considerable proportions since 16 new standards have emerged since 2002 to date. At the same time, the level of complexity of accounting standards has increased as it can be seen how the International Accounting Standards Manual has reached 1,800 pages, starting from several hundred pages.

This is how the "Annotated Blue Book" - The Annotated IFRS $®$ Standards-Standards Required 1 January 2018.

Among the most affected standards are financial instruments (IAS 32, IAS 39, IFRS 7, IFRS 9) or income (IAS 18, IAS 11, IFRS 15).

\section{The importance of accounting harmonization from the perspective of auditors}

We distributed a questionnaire to the auditors and accountants to determine the direction for a consistent application of International Accounting Standards and to analyze the perception of professionals about the impact of changes to International Accounting Standards.
We conducted an analysis of the results obtained by querying a sample of 18 professionals, using a scale of 1-5 (1 - Complete Disagreement, 2 - Disagreement, 3 - Neither Agreement, Disagreement, 4 - Agreed and 5 - Totally agree).

Thus, following the analysis of these results, the interpretations of the answers given to the questions below are the following:

A. Has the flexibility allowed by certain International Accounting Standards affected how audit work already worked?

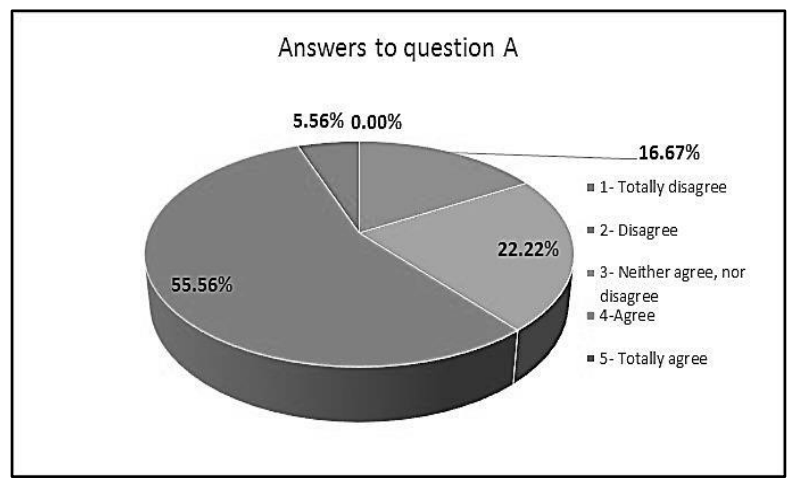

Source: Graph based of the answers to the questionnaire

$55.56 \%$ of the respondents consider that the flexibility allowed by certain International Accounting Standards has affected the way the audit work already done has been conducted because the analysis of the impact of options on the measurement of results is not missing from the worksheets.

On the other hand, $16.67 \%$ of professionals believe that predefined auditing tests are designed to detect distortions based on the risks identified, without being conditioned by the manner in which accounting choices are justified. The accounting standard has both basic treatment and alternative treatment, and both are reflected in the audit tests to verify them.

Based on the experience gained, most changes to the audit approach are influenced by the primary objective of ensuring accurate information in the accounting system, in line with applicable accounting standards, and with appropriate legislation.

The overall conclusion reflects how important it is for auditing tests to be tailored to the requirements of approach and risks identified by collecting adequate, sufficient, and credible audit evidence. 
B. Appropriate application of accounting standards contributes to reflecting a true image of the financial position and performance of the entity and the process of harmonization brings many benefits to the entity?

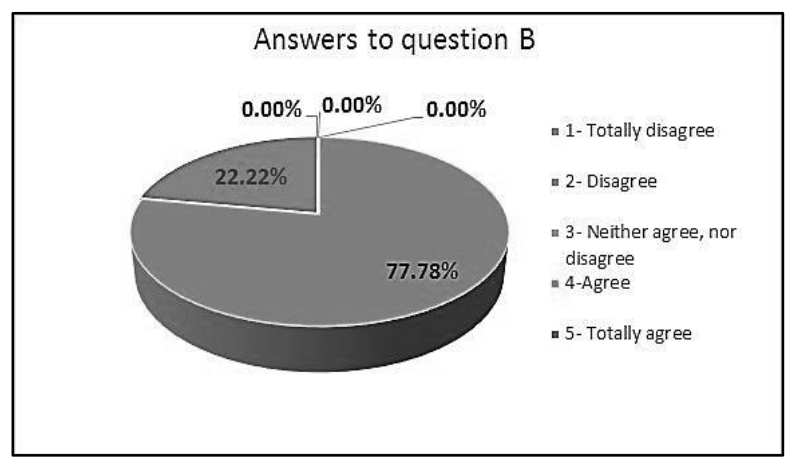

Source: Graph based of the answers to the questionnaire

$77.78 \%$ of professionals believe that proper application of accounting standards is based on professional judgment, which is a basic requirement for assessing the reflection of a true image of the entity's financial position and performance and $22.22 \%$ believe that the possibility of error is very small if the results of the harmonization process are also adopted within small companies.

To reach a common denominator, harmonization is the solution for all companies of all sizes and information users appreciate the same landmark system. Small businesses prefer to use cash accounting for simplicity, but the accrual accounting principle takes precedence to ensure comparability of information.

\section{Consistent application of International Accounting Standards does not lead to the development of creative accounting techniques and practices?}

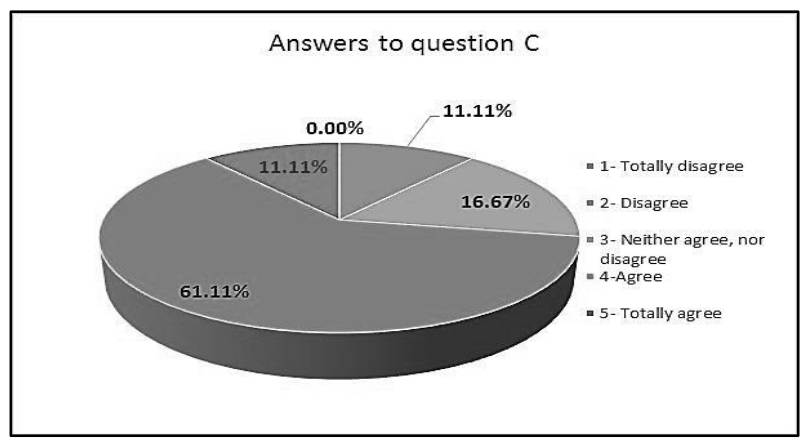

Source: Graph based of the answers to the questionnaire
$61.11 \%$ of respondents agree that consistent application of the Accounting Standards does not lead to the development of creative accounting techniques and practices. This consistency has a positive impact because it does not allow for ways to deviate from reality. Because the financial position and performance result of an entity is a unique reality, their reflection is true if the valuation of each transaction is in line with the economic outcome. The main way to achieve the muchdesired performance is to manage resources efficiently and to comply with the accounting rules and not through "accounting engineers".

$22.22 \%$ of professionals believe that Accounting Standards are one step behind the economic reality, which is often forced to adapt its rules. They consider the need to be creative and the most faithful results are achieved by completing normalization with creative engineering. Intentional accrual accounting is not the equivalent of negative creative accounting because it does not lead to legal or illegal transition

D. Financial statements are the result of updated International Accounting Standards, but the impact of changes is difficult to quantify most of the time?

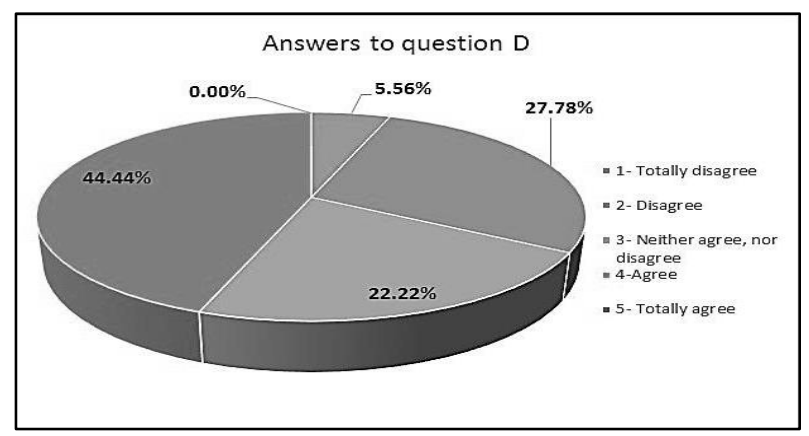

Source: Graph based of the answers to the questionnaire

$44.44 \%$ of surveyed professionals agreed that the impact of changes in financial statements prepared in accordance with International Accounting Standards is difficult to quantify because it requires an additional analysis based on many historical and comparative data that is not easily obtainable. For $27.78 \%$ of respondents, the impact of changes is easily quantifiable if the necessary resources are available because the costs for doing so are high, most of the time.

The normalizer aims to ensure comparability by updating existing accounting rules, so alignment with International Accounting Standards is vital. 
The impact of changes makes it felt every time through the results obtained in the audit tests. For example, the residual value and useful life of an asset need to be reviewed at least at the end of each financial year. Auditors verify whether there are differences from the latest estimates because they are to be accounted for as changes in accounting policies in accordance with IAS 8 "Accounting Policies, Changes in Accounting Estimates and Fundamental Errors".

Regulatory bodies have as their main reference the investors' vision, in other words they are focused on getting a useful presentation to investors, who want to certify the existence of a possible real gain.

\section{E. The more the International Accounting Standards} undergo several changes, the more the auditor's activity is most affected in terms of respecting ethical conduct?

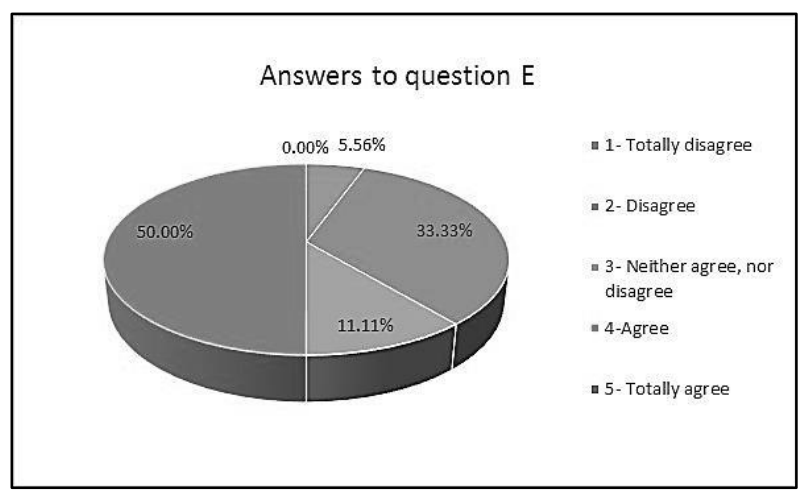

Source: Graph based of the answers to the questionnaire

Half of the respondents confirm the correlation between the amendments to International Accounting Standards and the auditor's work in respecting ethical conduct. The evolution of standards may generate conflicts of interest if the personal interests of an auditor appear to be likely to improperly influence the performance of its duties.

The independence of the auditor may be impaired if he cannot avoid any influence on the part of the client, however small he may "overlook" certain deviations from the provisions of the International Accounting Standards. Instead, $33.33 \%$ of professionals consider ethics to be very important, but they see no correlation between the changes to the standards and the impact on the auditor's activity from this point of view.
F. How are the International Accounting Standards undergoing more changes, the more the auditor's competence is more affected?

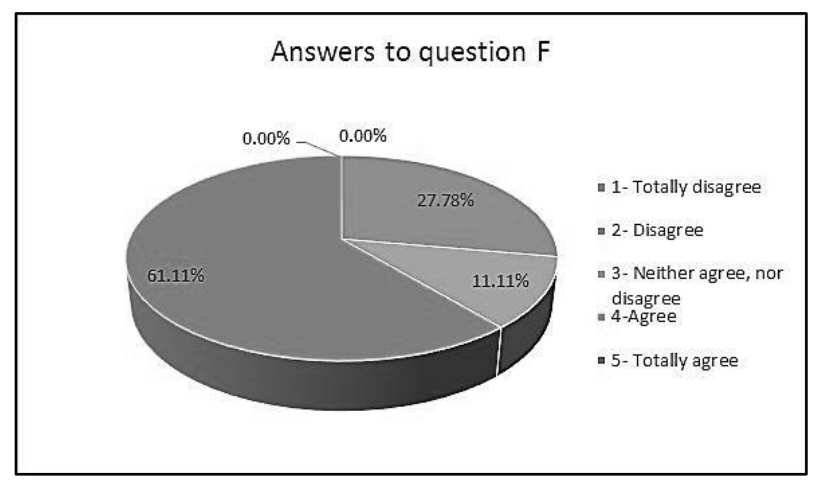

Source: Graph based of the answers to the questionnaire

$61.11 \%$ of those responding to the questionnaire consider the level of competence dependent on changes in standards. It is affected by any change and professional reasoning is not sufficient because without continuous professional development (CPD) it is easy to see the possibility of mistake and until negligence is just one step.

Every business often involves a certain risk, which must be first identified (whether it is a change in the legislation or comes from the applicable accounting rules). To deal with it, it is necessary to analyze the possible consequences and establish control measures (Adam, 2008). The main element in this analysis is the competence of the professional, either the accountant or the auditor, which leads to the proper application of the professional reasoning.

\section{Conclusions}

Based on the answers received from the auditors and accountants, most of the respondents consider it very important to apply the accounting policies in a consistent way in order to reflect a true image of the entity's financial position and financial performance, reflecting the consistency in the application of the options that have already been chosen.

During an audit mission, the audit evidence is collected to document and support the opinion of the audited financial statements.

Validating a financial quality report by reflecting the actual results of the entity's operations in the financial statements requires in-depth knowledge of the latest changes in 
auditing and accounting standards. All the standards need this evolution to make the economic system more efficient.

The appropriate identification of the audit risks and the design of the testing procedures, as well as the determination of the volume and format of the documentation are necessary for the formation of the audit opinion and depend on the manner in which the accounting standards have evolved.

The results obtained following a proper analysis are those that come next in line for the analysis, after performing the assessment related to the classification methods and to determine whether the appropriate techniques were adopted by the entity as this is the only way to the truth.

Ethical and professional conduct are impacted by the evolution of accounting standards because in order to demonstrate an optimal level of knowledge it is necessary to understand the latest developments of those standards, and in order to ensure the quality of the audit mission, it is necessary to observe the ethical principles, especially the principle of independence has to be fulfilled above all. To increase the confidence in the financial statements, professional bodies "fight" side by side with the professionals so that the legal framework is aligned with the accounting and auditing standards. Auditors have the courage to tell their clients that they have omitted certain provisions from the standards updates because the overall perception is about increasing the quality of the financial reporting.

There is always a risk of error, but the confidence in auditors increases as much as the confidence in customers is thoroughly checked by the audit tests designed to discover the risk points in the set of information. A higher degree of transparency is desired by accessing a thorough process of improving the quality of the reporting system.

\section{REFERENCES}

1. Adam, J. (2008), Growing business handbook: The inspiration and advice from successful entrepreneurs and fast growing UK companies, Ed. Kogan Page, London.

2. Antle, R. (1982), The Auditor as an Economic Agent, Journal of Accounting Research, vol.2, pp. 503-527.

3. Brief, R.P. (1975), The Accountant's Responsibility in Historical Perspective, The Accounting Review, vol. 50, №. 2, pp. 285-297.

4. Feleagă, N., Feleagă L. (2007), Contabilitate Financiară. $O$ abordare europeană şi internațională, vol. 1, Ed. Economică, Bucureşti.

5. Feleagă, N. (1996), Îmblânzirea junglei contabilității - concept şi normalizare în contabilitate, Editura Economică, Bucureşti.

6. Feleagă, N. (1999), Sisteme contabile comparate, vol. 1, Ed. Economică, Bucureşti.

7. Frecka, T.J (2008), Ethical Issues in Financial Reporting: Is Intentional Structuring of Lease Contracts to Avoid Capitalization Unethical?, Journal of Business Ethics, vol. 80, No. 1, pp. 45-59.

8. Gîrbină, M. M, Bunea, Şt. (2008), Sinteze, Studii de caz şi teste grilă privind aplicarea IAS (revizuite) IFRS, vol. II, Ed. CECCAR, Bucureşti.

9. Salterand, S.B and Niswander, F. (1995), Cultural Influence on the Development of Accounting Systems Internationally: A Test of Gray's [1988]
Theory, Journal of International Business Studies, vol. 26, No. 2, pp. 379-397.

10. Stănciulescu, B. M. (2008), Normalizarea contabilității din România. Între national şi internațional, Bucureşti, (Conducător Ştiințific Prof. univ. dr. Mihai Ristea).

11. Toma, C. (2012), Rolul auditului în creşterea calității informațiilor financiare, Revista Audit Financiar, pp. 5-13.

12. Togoe, D. (2012), Fundamental Principles and Conduct Rules in Audit, Revista Română de Statistică - Supliment Trim IV/2012, pp. 451-454.

13. Shafer, W. E, Ketchand A. A and Morris R. E. (2004), Auditors' Willingness to Advocate ClientPreferred Accounting Principles, Journal of Business Ethics, vol. 52, No. 3, pp. 213- 227.

14. http://www.iasplus.com/en/meeting-notes/ifrs-ic/notadded/2010/ias-1-financial-statement-presentation

15. www.oecd.org/gov/regulatory-policy/ria.htm

16. https://www.icaew.com//media/corporate/files/technical/audit-andassurance/audit-quality/audit-quality-forumevolution/evolution-changes-in-financial-reportingand-audit-practice.ashx

17. http://agvps.ro/docs/manual\%20de\%20politici\%20co ntabile.pdf 